\title{
Studies of Beryllium Chromite and Other Beryllia Compounds With $\mathrm{R}_{2} \mathrm{O}_{3}$ Oxides
}

\author{
C. E. Weir and A. Van Valkenburg
}

(August 10, 1959)

\begin{abstract}
Reactions ketween $\mathrm{BeO}$ and $\mathrm{R}_{2} \mathrm{O}_{3}$ oxides at high temperatures were studied. Compound formation was observed between $\mathrm{BeO}$ and the following oxides: $\mathrm{B}_{2} \mathrm{O}_{3}, \mathrm{Al}_{2} \mathrm{O}_{3}, \mathrm{Ga}_{2} \mathrm{O}_{3}$, $\mathrm{Y}_{2} \mathrm{O}_{3}$, $\mathrm{La}_{2} \mathrm{O}_{3}$, and $\mathrm{Cr}_{2} \mathrm{O}_{3}$. No reaction was observed with $\mathrm{Sc}_{2} \mathrm{O}_{3}, \mathrm{In}_{2} \mathrm{O}_{3}$, and $\mathrm{Fe}_{2} \mathrm{O}_{3}$. Detailed studies were made of $\mathrm{BeO} \cdot \mathrm{Cr}_{2} \mathrm{O}_{3}$ which is isostructural with $\mathrm{BeO} \cdot \mathrm{Al}_{2} \mathrm{O}_{3}$. $\mathrm{BeO} \cdot \mathrm{Cr}_{2} \mathrm{O}_{3}$ is a semiconductor. Optical and $\mathrm{X}$-ray data are given for all reaction products.
\end{abstract}

\section{Introduction}

In hydrothermal experiments involving the system $\mathrm{BeO}+\mathrm{Al}_{2} \mathrm{O}_{3}+\mathrm{SiO}_{2}$ with small amounts of added $\mathrm{Cr}_{2} \mathrm{O}_{3}$ at $850^{\circ} \mathrm{C}$, it was found that X-ray patterns of reaction products persistently showed evidence for an unidentified material. It was found that this material was a compound between $\mathrm{BeO}$ and $\mathrm{Cr}_{2} \mathrm{O}_{3}$. The compound has been reported earlier to be $\mathrm{BeO} \cdot \mathrm{Cr}_{2} \mathrm{O}_{3}$ by Lang, Roth, and Fillmore [1] who studied the system $\mathrm{BeO}-\mathrm{Cr}_{2} \mathrm{O}_{3}-\mathrm{ZrO}_{2}$. They found that it was orthorhombic, isostructural with $\mathrm{BeO} \cdot \mathrm{Al}_{2} \mathrm{O}_{3}$, with unit call parameters $a=10.0 \mathrm{~A}$, $b=5.8 \mathrm{~A}$, and $c=4.5 \mathrm{~A}$. The present report describes the preparation and some of the properties of $\mathrm{BeO} \cdot \mathrm{Cr}_{2} \mathrm{O}_{3}$ as well as preliminary studies on the reactions between $\mathrm{BeO}$ and the $\mathrm{R}_{2} \mathrm{O}_{3}$ oxides in group III of the periodic system.

\section{Experimental Materials and Methods}

All reagents used were oxides of reagent grade except $\mathrm{Ga}_{2} \mathrm{O}_{3}, \mathrm{In}_{2} \mathrm{O}_{3}$, and $\mathrm{Y}_{2} \mathrm{O}_{3}$. The former two were made by solution of chemically pure metal in nitric acid followed by thermal decomposition of the nitrate. The available specimen of $\mathrm{Y}_{2} \mathrm{O}_{3}$ was of commercial origin with a purity of 99.7 percent.

Hydrothermal reactions were carried out in the well-known cold-seal apparatus [2], using platinum containers. Solid state reactions were made through repeated heating and grinding of oxides. Materials were heated to temperatures as high as $1,550^{\circ} \mathrm{C}$ in platinum, while $\mathrm{BeO}$ containers were used between $1,550^{\circ} \mathrm{C}$ and $2,100^{\circ} \mathrm{C}$. Temperatures to $1,550^{\circ}$ $\mathrm{C}$ were obtained with platinum wire furnaces and higher temperatures with a carbon resistance furnace using a He atmosphere. Early results indicated the desirability of a rapid screening process. This was accomplished by using a small $\mathrm{d}-\mathrm{c}$ carbon arc as a furnace. Component oxides were mixed and treated with a sufficient quantity of 10 percent aqueous starch solution to form a paste. The paste was extruded from glass tubing to form small rods $1 / 8 \mathrm{in}$. in diameter, which were dried and melted in the are using the tubing as a handle. All oxides studied were melted rapidly in the arc and a single

1 Figures in brackets indicate the literature references at the end of this paper. small fused bead was sufficient to permit X-ray and microscopic analysis. The possible reduction and volatilization of the oxides precludes knowledge of the purity or composition of the arc-fused product, but rapid search for reactions is quite simple with this method.

\section{Results \\ 3.1. $\mathrm{BeO} \cdot \mathrm{Cr}_{2} \mathrm{O}_{3}$}

This material formed hydrothermally at temperatures as low as $800^{\circ} \mathrm{C}$ in the presence of water. In this temperature range, however, the reaction rate is very low and crystals are very small.

In the solid state, slow reaction was observed at temperatures as low as $1,400^{\circ}$ C. Microscopic comparisons of the surface with the body of specimens showed that prolonged heating of oxide mixtures at $1,450^{\circ} \mathrm{C}$ produces some surface loss of $\mathrm{Cr}_{2} \mathrm{O}_{3}$. The loss accelerates as the temperature is raised so that only $\mathrm{BeO}$ crystals remain on the surface after $4 \mathrm{hr}$ at $1,750^{\circ} \mathrm{C}$. Below about $1,600^{\circ} \mathrm{C}$ the rate of loss is believed to be sufficiently low that the bulk composition is essentialiy unaffected in normal heating periods. That the $\mathrm{Cr}_{2} \mathrm{O}_{3}$ vapor was at least partially due to vapor pressure of the compound was shown by the fact that $\mathrm{BeO} \cdot \mathrm{Cr}_{2} \mathrm{O}_{3}$ sintered in $\mathrm{BeO}$ at $1,750^{\circ} \mathrm{C}$ also showed much surface loss of $\mathrm{Cr}_{2} \mathrm{O}_{3}$. The competitive processes of reaction of the oxides and vaporization of $\mathrm{Cr}_{2} \mathrm{O}_{3}$ from the oxide mixture and the compound indicate that there is an optimum temperature for formation of $\mathrm{BeO} \cdot \mathrm{Cr}_{2} \mathrm{O}_{3}$. These experiments indicate that this temperature is probably between $1,300^{\circ} \mathrm{C}$ and $1,600^{\circ}$ C. As a result of vaporization of $\mathrm{Cr}_{2} \mathrm{O}_{3}$ large single crystals would not be expected in open systems; however, crystals as large as $0.05 \mathrm{~mm}$ are readily formed under these conditions. The compound forms readily in the arc crystallizing from the liquid phase. Experiments in the arc also showed that the compound $\mathrm{BeO} \cdot \mathrm{Cr}_{2} \mathrm{O}_{3}$ was a semiconductor as conductivity of specimens became so high at elevated temperatures that resistance heating could be effected.

Microscopic examination showed that $\mathrm{BeO} \cdot \mathrm{Cr}_{2} \mathrm{O}_{3}$ forms well-terminated, transparent, deep green crystals having a reddish pleochroism. The crystals are biaxial negative with $2 \mathrm{~V} \approx 45^{\circ}$ and indices, $\alpha=2.143$, $\beta$ not measured, $\gamma=2.230$. Pseudohexagonal, highly 
TABLE 1. X-ray powder pattern for $\mathrm{BeO} \cdot \mathrm{Cr}_{2} \mathrm{O}_{3}$

\begin{tabular}{c|r|r}
\multicolumn{3}{c}{$\mathrm{Cu} \mathrm{K}_{\alpha}, \lambda=1.5405$} \\
\hline \multicolumn{3}{|c}{$\mathrm{BeO} \cdot \mathrm{Cr}_{2} \mathrm{O}_{3}{ }^{1}$} \\
\hline$d_{\text {obs. }}$ & \multicolumn{1}{|c}{$h k l$} & $d_{\text {calc. }}$ \\
\hline & & \\
4 & & $A$ \\
4.135 & 101 & 4.131 \\
3.337 & 111 & 3.337 \\
2.653 & 301 & 2.644 \\
2.452 & 220 & 2.451 \\
2.402 & 311 & 2.403 \\
2.335 & 121 & 2.335 \\
2.157 & 401 & 2.157 \\
1.936 & 321 & 1.936 \\
1.715 & $\{421$ & 1.715 \\
1.668 & 2211 & 1.716 \\
1.539 & & 1.669 \\
1.519 & 331 & 1.538 \\
1.4159 & 003 & 1.519 \\
1.4140 & 040 & 1.4155 \\
1.3765 & 620 & 1.4141 \\
& 303 & 1.3771 \\
& & \\
\hline
\end{tabular}

1 Unit cell parameters $a=9.792 \mathrm{~A}, b=5.663 \mathrm{~A}, c=4.555 \mathrm{~A}$; calculated density $4.654 \mathrm{~g} / \mathrm{cm}^{3}$ at $25^{\circ} \mathrm{C}$.

twinned crystals similar to those of $\mathrm{BeO} \cdot \mathrm{Al}_{2} \mathrm{O}_{3}$ are obtained on reaction via the liquid phase.

Polycrystalline material appears black and opaque. It has a hardness on the Moh's scale of about 9 by the scratch test. The melting point was not measured but it was found that a eutectic between $\mathrm{BeO}$ and $\mathrm{BeO} \cdot \mathrm{Cr}_{2} \mathrm{O}_{3}$ melts below approximately $2,050^{\circ} \mathrm{C}$. The measured specific gravity is 4.42 and the principal $\mathrm{X}$-ray powder lines are given in table 1 with the indices and unit cell parameters. X-ray studies conducted on mixtures rich in $\mathrm{BeO}$ or $\mathrm{Cr}_{2} \mathrm{O}_{3}$ showed no appreciable solid solution of the parent oxides in $\mathrm{BeO} \cdot \mathrm{Cr}_{2} \mathrm{O}_{3}$.

X-ray powder patterns show $\mathrm{BeO} \cdot \mathrm{Al}_{2} \mathrm{O}_{3}$ and $\mathrm{BeO} \cdot \mathrm{Cr}_{2} \mathrm{O}_{3}$ are isostructural. Several solid solutions were prepared from the component oxides and the variation of the unit cell parameters with composition is shown in figure 1. Although some curvature is possible in the variation of "a" with composition, the deviations from linearity are probably within the experimental error of determining the cell parameters. In addition the compositions denoted by the points are determined from the known quantities of oxides added and may be subject to some error arising from loss of $\mathrm{Cr}_{2} \mathrm{O}_{3}$ on firing. This error is believed to be small. From these data it appears that a complete series of solid solutions exists between $\mathrm{BeO} \cdot \mathrm{Al}_{2} \mathrm{O}_{3}$ and $\mathrm{BeO} \cdot \mathrm{Cr}_{2} \mathrm{O}_{3}$. This conclusion differs from that of Gjessing, Larrson, and Major [3] who found only partial substitution of $\mathrm{Cr}_{2} \mathrm{O}_{3}$ for $\mathrm{Al}_{2} \mathrm{O}_{3}$ in the $\mathrm{BeO} \cdot \mathrm{Al}_{2} \mathrm{O}_{3}$ structure.

In view of the electrical conductivity of $\mathrm{BeO} \cdot \mathrm{Cr}_{2} \mathrm{O}_{3}$ at elevated temperatures, it was of interest to determine the temperature-resistance characteristics. These measurements were made on polycrystalline sintered bars using platinum electrodes. Specimens were measure in a temperature-controlled furnace using a commercial megohm bridge which applied $500 \mathrm{v}$ across the specimen. Since single crystals were not used, and the bars possessed pores, the resistivities could not be determined, the resulting data

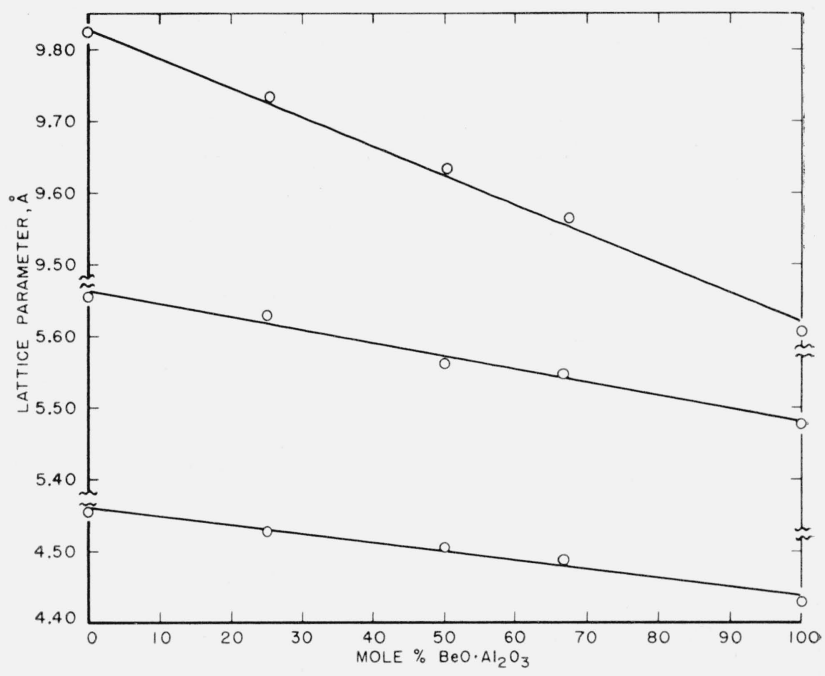

FIGURE 1. Variation of unit cell paramsters in the solid solution series $\mathrm{BeO} \cdot \mathrm{Al}_{2} \mathrm{O}_{3}-\mathrm{BeO} \cdot \mathrm{Cr}_{2} \mathrm{O}_{3}$.

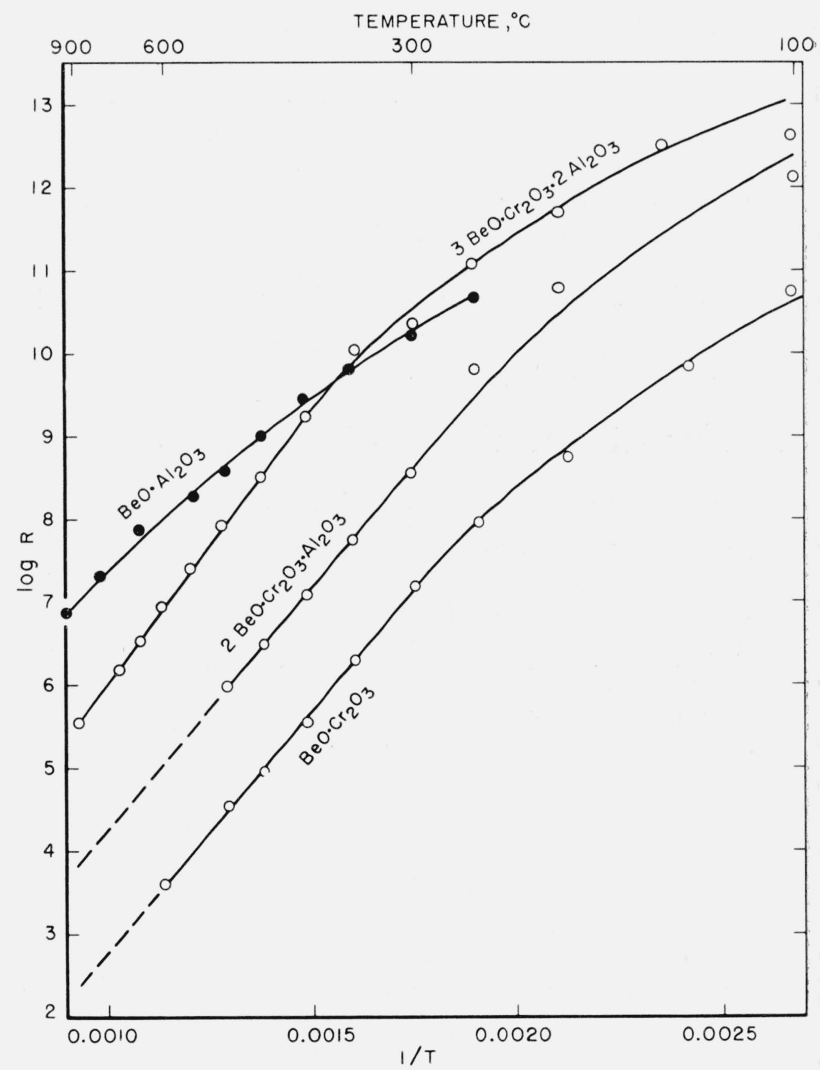

Figure 2. Temperature variation of resistance of $\mathrm{BeO} \cdot \mathrm{Al}_{2} \mathrm{O}_{3}$, $\mathrm{BeO} \cdot \mathrm{Cr}_{2} \mathrm{O}_{3}$ and solid solutions.

being valid only for showing the temperature dependence of resistance. The resistance was measured at temperature intervals of approximately $100^{\circ} \mathrm{C}$ and the data are shown for $\mathrm{BeO} \cdot \mathrm{Cr}_{2} \mathrm{O}_{3}$ as well as $\mathrm{BeO} \cdot \mathrm{Al}_{2} \mathrm{O}_{3}$ and two solid solutions in figure 2. The data are plotted in the usual manner using $1 / T$ and $\log \mathrm{R}$. From the figure it will be observed that data for 
specimens containing $\mathrm{Cr}_{2} \mathrm{O}_{3}$ are not inconsistent with the interpretation that they are intrinsic semiconductors, above about $300^{\circ} \mathrm{C}$. If this interpretation is correct the average energy gap is calculated to be $2.4 \mathrm{ev}$ and appears to be independent of the $\mathrm{Al}_{2} \mathrm{O}_{3} / \mathrm{Cr}_{2} \mathrm{O}_{3}$ ratio.

The magnetic characteristics of $\mathrm{BeO} \cdot \mathrm{Cr}_{2} \mathrm{O}_{3}$ are being studied by W. E. Henry of the Naval Research Laboratory. Preliminary results show the material to be antiferromagnetic.

\section{2. $\mathrm{BeO}-\mathrm{R}_{2} \mathrm{O}_{3}$ Reactions}

\section{a. $\mathrm{BeO}-\mathrm{B}_{2} \mathrm{O}_{3}$}

A crystalline product is formed by heating $\mathrm{BeO}$ and crystalline $\mathrm{B}_{2} \mathrm{O}_{3}$ at $800^{\circ} \mathrm{C}$. The principal $\mathrm{X}$-ray lines for the material are given in table 2 . Crystals are biaxial with $2 \mathrm{~V} \approx 90^{\circ}$ and indices $\alpha=1.62, \beta$ not measured, $\gamma=1.574$. The material is not isostructural with $\mathrm{BeO} \cdot \mathrm{Al}_{2} \mathrm{O}_{3}$. From the X-ray pattern the product can be identified with the compound $3 \mathrm{BeO} \cdot \mathrm{B}_{2} \mathrm{O}_{3}$ reported by Menzel and Sliwinski [4] and by Mazelev [5].

TABLE 2. X-ray pouder patterns for $\mathrm{BeO} \cdot \mathrm{R}_{2} \mathrm{O}_{3}$ compounds $\mathrm{Cu} \mathrm{K} \alpha, \lambda=1.5405$

\begin{tabular}{|c|c|c|c|c|c|c|c|c|c|}
\hline \multicolumn{2}{|c|}{$3 \mathrm{BeO} \cdot \mathrm{B}_{2} \mathrm{O}_{3}$} & \multicolumn{4}{|c|}{$\mathrm{BeO} \cdot 2 \mathrm{Ga}_{2} \mathrm{O}_{3}$} & \multicolumn{2}{|c|}{$\mathrm{nBeO} \cdot \mathrm{Y}_{2} \mathrm{O}_{3}$} & \multicolumn{2}{|c|}{$\mathrm{nIBeO} \cdot \mathrm{La}_{2} \mathrm{O}_{3}$} \\
\hline$d, A$ & $I$ & $d, . A$ & hlill & $I$ & $d_{c a l c .}$. & $d, A$ & $I$ & $d, A$ & $I$ \\
\hline 7. 302 & $v w$ & 6717 & 100 & $m$ & 6. 716 & 7.190 & w & 3. 768 & vs \\
\hline 6. 067 & w & 3.875 & 110 & $m$ & 3.877 & 5. 196 & w & 3. 718 & $\mathrm{~m}$ \\
\hline 5.921 & w & 3. 3-9 & 200 & $s$ & $3.35 \mathrm{~s}$ & 4. 607 & $\mathrm{VW}$ & 3.673 & $\mathrm{~m}$ \\
\hline 3.967 & m & 2. 728 & 101 & s & 2. 723 & 4. 469 & s & 3. 296 & $\mathrm{~m}$ \\
\hline 3.872 & vs & 2. 539 & 210 & vs & 2. 538 & 3. 146 & $\mathrm{~m}$ & 3. 063 & $\mathrm{~m}$ \\
\hline 3.826 & in & 2. 230 & 202 & s & 2. 228 & 2. 922 & rs & 3. 008 & $\mathrm{~s}$ \\
\hline $3.63 i$ & $\mathrm{~m}$ & 1.938 & 220 & W & 1. 939 & 2. 838 & $\mathrm{~m}$ & 2. 631 & $\mathrm{~m}$ \\
\hline 3.188 & $\mathrm{~s}$ & 1. 934 & 211 & w & 1. 932 & 2. 786 & $\mathrm{~m}$ & 2. 628 & $\mathrm{~m}$ \\
\hline 2.901 & s & 1. 863 & 30 & w & 1. 863 & 2. 765 & w & 2. 620 & $\mathrm{~m}$ \\
\hline 2.863 & w & 1. 791 & 301 & m & 1. 790 & 2. 600 & w & 2. +12 & s \\
\hline 2.718 & w & 1. 626 & 221 & W & 1. 625 & 2. 479 & w & 2. 494 & $\mathrm{~m}$ \\
\hline 2.480 & $\mathrm{~m}$ & 1. 579 & 311 & w & 1. 579 & 2. 412 & w & 2. 465 & w \\
\hline 2. 446 & w & 1. 541 & 320 & w & 1. 541 & 2. 213 & w & 2. 224 & w \\
\hline 2.365 & w & 1. 489 & 002 & w & 1. 495 & 2. 193 & w & 2. 167 & $\mathrm{~m}$ \\
\hline 2. 204 & w & 1.465 & 410 & w & 1. 466 & 2. 060 & w & 2. 127 & $\mathrm{~m}$ \\
\hline 2. 168 & w & 1. 369 & 321 & m & 1. 369 & 1. 979 & $\mathrm{~m}$ & 2.055 & w \\
\hline 2.061 & w & 1. 316 & 411 & w & 1. 316 & 1. 975 & w & 2. 030 & w \\
\hline 1. 932 & $w$ & 1. 286 & 212 & w & 1. 286 & 1. 945 & w & 1. 980 & $\mathrm{~m}$ \\
\hline 1.901 & w & 1. 269 & 420 & $\mathrm{vW}$ & 1. 269 & 1.888 & w & 1. 965 & W \\
\hline 1. 751 & w & 1. 207 & 510 & vw & 1. 206 & 1. 767 & $\mathrm{~m}$ & 1. 883 & $\mathrm{~m}$ \\
\hline 1. 737 & w & 1. 183 & 222 & $\mathrm{vw}$ & 1. 182 & 1. 705 & W & 1.838 & w \\
\hline 1. 656 & w & 1. 169 & 421 & VW & 1. 168 & 1. 682 & w & 1. 820 & w \\
\hline 1. 430 & w & & & $\ldots$ & 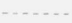 & 1. 631 & w & 1. 785 & $\mathrm{~m}$ \\
\hline 1. 275 & w & & & & & 1. 460 & $w$ & 1. 763 & $\mathrm{~m}$ \\
\hline & & & & & & 1. 455 & w & 1. 740 & w \\
\hline & & & & & & 1. 289 & w & 1. 700 & w \\
\hline & & & & & & & & 1. 698 & w \\
\hline & & & & & & & & 1. 678 & W \\
\hline & & & & & & & & 1. 652 & w \\
\hline & & & & & & & & $\begin{array}{l}1.647 \\
1.638\end{array}$ & $\begin{array}{l}\text { W } \\
\text { W }\end{array}$ \\
\hline & & & & & & & & 1. 627 & w \\
\hline & & & & & & & & 1. 610 & w \\
\hline & & & & & & & & 1. 608 & w \\
\hline & & & & & & & & 1. 542 & w \\
\hline & & & & & & & & 1.515 & w \\
\hline & & & & & & & & 1. 483 & w \\
\hline & & & & & & & & 1. 446 & $\mathrm{~m}$ \\
\hline & & & & & & & & 1. 209 & W \\
\hline & & & & & & & & .201 & $\mathrm{~m}$ \\
\hline
\end{tabular}

1 Indexed on the basis of a hexagonal unit cell with parameters $a=7.78 \mathrm{~A}$ and $c=2.98 \mathrm{~A}$.

\section{b. $\mathrm{BeO}-\mathrm{Al}_{2} \mathrm{O}_{3}$}

In addition to $\mathrm{BeO} \cdot \mathrm{Al}_{2} \mathrm{O}_{3}$, the product $\mathrm{BeO} \cdot 3 \mathrm{Al}_{2} \mathrm{O}_{3}$ is readily formed by are fusion of the $1: 3$ oxide mixture. This material is identified with the X-ray powder pattern given originally by Foster and Royal [6] and extended by Budnikov et al. [7].

$$
\text { c. } \mathrm{BeO}-\mathrm{Sc}_{2} \mathrm{O}_{3}
$$

Mixtures of $\mathrm{BeO}$ and $\mathrm{Sc}_{2} \mathrm{O}_{3}$ can be fused with difficulty in the arc. However, despite numerous attempts no evidence for reaction was observed. X-ray powder patterns of fused beads showed only $\mathrm{BeO}$ and $\mathrm{Sc}_{2} \mathrm{O}_{3}$ lines.

\section{d. $\mathrm{BeO}-\mathrm{Ga}_{2} \mathrm{O}_{3}$}

Are fusion studies showed reaction between $\mathrm{BeO}$ and $\mathrm{Ga}_{2} \mathrm{O}_{3}$, but $\mathrm{X}$-ray patterns showed the product was not isostructural with $\mathrm{BeO} \cdot \mathrm{Al}_{2} \mathrm{O}_{3}$. Gjessing, Larrson, and Major [3] have previously reported a compound, $\mathrm{BeO} \cdot 2 \mathrm{Ga}_{2} \mathrm{O}_{3}$, which is not isostructural with $\mathrm{BeO} \cdot \mathrm{Al}_{2} \mathrm{O}_{3}$. Solid state reactions indicated that the material was readily formed at $1,350^{\circ}$ from a mixture of oxides. Although complete reaction was not obtained in short periods at this temperature as shown by X-ray lines of unreacted $\mathrm{BeO}$ or $\mathrm{Ga}_{2} \mathrm{O}_{3}$ the product is believed to be identical with the $\mathrm{BeO} \cdot 2 \mathrm{Ga}_{2} \mathrm{O}_{3}$ reported earlier [3]. Microscopic examination showed the material to be uniaxial positive with indices 1.747 and 1.774 . The $\mathrm{X}$-ray powder pattern lines given in table 2 were obtained by deleting the known lines of $\mathrm{BeO}$ from the pattern. This pattern has been indexed in the hexagonal system with $a=7.78 \mathrm{~A}$ and $c=2.98 \mathrm{~A}$, with the indices given in table 2 .

$$
\text { e. } \mathrm{BeO}-\mathrm{Y}_{2} \mathrm{O}_{3}
$$

Arc fusion studies showed reaction between $\mathrm{BeO}$ and $\mathrm{Y}_{2} \mathrm{O}_{3}$. All attempts to produce a similar material by solid state reactions at temperatures as high as $1,600^{\circ} \mathrm{C}$ were unsuccessful. Therefore the composition as well as the purity of the material are not known. Microscopic examination showed biaxial crystals with $2 \mathrm{~V} \approx 90^{\circ}$ and indices, $\alpha=1.84$, $\beta$ not measured, $\gamma=1.85$. The X-ray powder pattern lines are listed in table 2 but it should be noted that extraneous lines from impurities introduced by the are may be present. This material is obviously not isostructural with $\mathrm{BeO} \cdot \mathrm{Al}_{2} \mathrm{O}_{3}$ and does not appear to have been reported previously.

\section{f. $\mathrm{BeO}-\mathrm{In}_{2} \mathrm{O}_{3}$}

Repeated efforts at high and low temperatures, in open and closed systems, both with and without water present failed to give any evidence for reaction. Ensslin and Valentiner [8] reported $\mathrm{BeO} \cdot \mathrm{In}_{2} \mathrm{O}_{3}$ as having the same lattice constant as $\mathrm{In}_{2} \mathrm{O}_{3}$. Gjessing, Larrson, and Major [3] found no reaction. On the basis of the present work it is concluded that reaction between the oxides does not occur to $1,600^{\circ} \mathrm{C}$.

\section{g. $\mathrm{BeO}-\mathrm{La}_{2} \mathrm{O}_{3}$}

These oxides react readily in the arc. Solid state reactions may be carried out at $1,300^{\circ} \mathrm{C}$ and indicate that the product is probably $2 \mathrm{BeO} \cdot \mathrm{La}_{2} \mathrm{O}_{3}$. Microscopic examination shows biaxial crystals with $2 \mathrm{~V} \approx 90^{\circ}$ having indices, $\alpha=1.995, \beta$ not measured, $\gamma=2.047$. X-ray powder pattern lines are given in table 2 . 


\section{h. $\mathrm{BeO}-\mathrm{Cr}_{2} \mathrm{O}_{3}$}

In addition to the compound $\mathrm{BeO} \cdot \mathrm{Cr}_{2} \mathrm{O}_{3}$ the question of a $1: 3$ compound analogous to $\mathrm{BeO} \cdot 3 \mathrm{Al}_{2} \mathrm{O}_{3}$ was investigated. Evidence was found that only the 1:1 compound was formed, X-ray patterns showing lines for $\mathrm{BeO} \cdot \mathrm{Cr}_{2} \mathrm{O}_{3}$ and $\mathrm{Cr}_{2} \mathrm{O}_{3}$ only.

$$
\text { i. } \mathrm{BeO}-\mathrm{Fe}_{2} \mathrm{O}_{3}
$$

Several experiments were performed to prepare the $\mathrm{Beo} \cdot \mathrm{Fe}_{2} \mathrm{O}_{3}$ analog of $\mathrm{BeO} \cdot \mathrm{Al}_{2} \mathrm{O}_{3}$ starting from the oxides. None were successful. In most instances $\mathrm{Fe}_{3} \mathrm{O}_{4}$ was formed. The question of the existence of $\mathrm{BeO} \cdot \mathrm{Fe}_{2} \mathrm{O}_{3}$ from previous work is not clear $[9,3]$. However, from the present experiments it appears that such a compound does not form from the oxides at temperatures up to the liquidus.

\section{Summary}

High temperature reactions of $\mathrm{BeO}$ with the $\mathrm{R}_{2} \mathrm{O}_{3}$ oxides have been studied.The compound $\mathrm{BeO} \cdot \mathrm{Cr}_{2} \mathrm{O}_{3}$ has been studied in some detail. It is isostructural with $\mathrm{BeO} \cdot \mathrm{Al}_{2} \mathrm{O}_{3}$ and a continuous series of solid solutions forms between these compounds. The unit cell parameters in the solid solutions show nearly ideal behavior. $\mathrm{BeO} \cdot \mathrm{Cr}_{2} \mathrm{O}_{3}$ is a semiconductor.
Compound formation was verified between $\mathrm{BeO}$ and the following oxides: $\mathrm{B}_{2} \mathrm{O}_{3}, \mathrm{Ga}_{2} \mathrm{O}_{3}, \mathrm{Y}_{2} \mathrm{O}_{3}$, and $\mathrm{La}_{2} \mathrm{O}_{3}$. Powder X-ray diffraction patterns are given for all compounds and that for $\mathrm{BeO} \cdot 2 \mathrm{Ga}_{2} \mathrm{O}_{3}$ is indexed in the hexagonal system. No reaction was observed between $\mathrm{BeO}$ and $\mathrm{Sc}_{2} \mathrm{O}_{3}, \mathrm{In}_{2} \mathrm{O}_{3}$, and $\mathrm{Fe}_{2} \mathrm{O}_{3}$.

The authors thank Mrs. Eloise Evans for indexing the $\mathrm{BeO} \cdot \mathrm{Cr}_{2} \mathrm{O}_{3} \mathrm{X}$-ray pattern.

\section{References}

[1] S. M. Lang, R. S. Roth, and C. L. Fillmore, J. Research NBS 53, 201 (1954) RP2534.

[2] J. Van den Huerk, Bull. Geol. Soc. Am. 54, 993 (1953).

[3] L. Gjessing, T. Larrson, and H. Major, Norsk Geol. Tidsskr. 22, 92 (1942).

[4] H. Menzel and S. Sliwinski, Z. anorg. u. allgem. Chem. 249, 357 (1942).

[5] L. Y. Mazelev, Izvest. Akad. Nauk Belorus S.S.R. 4, 105 (1953).

[6] W. R. Foster and H. F. Royal, J. Am. Ceram. Soc. 32, 26 (1949).

[7] P. P. Budnikov, V. G. Avetikov, E. I. Dudavskii, and A. A. Zvyagilskii, Doklady Akad. Nauk S.S.S.R. 68, 313 (1949).

[8] F. Ensslin and S. Valentiner, Z. Naturforsch. 2B, 5 (1947).

[9] A. Michel, Ann. chim. 8, 352 (1937).

Washington, D.C.

(Paper 64A1-31). 